\title{
Influence of brine concentration on sugar and sodium chloride diffusion during the processing of the green olive variety Arauco
}

\author{
By M. B. Maldonado, C. A. Zuritz, ${ }^{*}$ and N. Miras
}

CONICET, Argentina (* corresponding author: cazuritz@ infovia.com.ar)

\begin{abstract}
RESUMEN
Influencia de la concentración de la salmuera en la difusión de azúcares y cloruro de sodio durante el procesamiento de aceitunas verdes variedad Arauco.

Aceitunas verdes variedad Arauco fueron tratadas con soluciones de hidróxido de sodio al 2,5\%. Estas fueron luego sometidas a dos procesos de lavado con agua corriente. Posteriormente, las aceitunas fueron curadas en salmueras con concentraciones de $7 \%, 10 \%$ y $13 \%$ de cloruro de sodio. Durante este proceso de curado, se cuantificó la pérdida de azúcares reductores desde, y la difusión de cloruro de sodio hacia el interior de las aceitunas. Durante este período se calcularon los coeficientes efectivos de difusión de ambos solutos en la piel y la pulpa, utilizando un modelo de difusión en una esfera hueca compuesta. Los coeficientes efectivos de difusión de ambos solutos en la piel estuvieron en un rango entre $8,27 \times 10^{-14} \mathrm{~m}^{2} / \mathrm{s}$ y $4,04 \times 10^{-13} \mathrm{~m}^{2} / \mathrm{s}$. Los coeficientes de la pulpa variaron entre $2,92 \times 10^{-9} \mathrm{~m}^{2} / \mathrm{s}$ y $3,99 \times 10^{-9} \mathrm{~m}^{2} / \mathrm{s}$ para el cloruro de sodio, y entre $9,76 \times 10^{-11} \mathrm{~m}^{2} / \mathrm{s}$ y $2,22 \times 10^{-10}$ $\mathrm{m}^{2} / \mathrm{s}$ para los azúcares reductores.
\end{abstract}

PALABRAS CLAVE: Aceitunas verdes - Azúcares reductores - Cloruro de sodio - Difusión - Tratamiento alcalino.

\section{SUMMARY}

Influence of brine concentration on sugar and sodium chloride diffusion during the processing of the green olive variety Arauco.

The green olive variety Arauco were debittered using lye concentrations of, $2.50 \% \mathrm{NaOH}$. They were then subjected to two rinsing processes with tap water. Next, the olives were cured with brines at $7 \%, 10 \%$ and $13 \%$ sodium chloride concentration. During this curing process, the loss of reducing sugars from the olives, and the diffusion of sodium chloride into the olives were quantified. Effective diffusion coefficients of both solutes in the skin and the flesh were calculated for this period using a diffusion model for a composite hollow sphere. The skin effective diffusion coefficients for both solutes ranged from $8.27 \times 10^{-14} \mathrm{~m}^{2} / \mathrm{s}$ to $4.04 \times 10^{-13} \mathrm{~m}^{2} / \mathrm{s}$. The flesh coefficients varied from $2.92 \times 10^{-9}$ $\mathrm{m}^{2} / \mathrm{s}$ to $3.99 \times 10^{-9} \mathrm{~m}^{2} / \mathrm{s}$ for sodium chloride and from $9.76 \times 10^{-}$ ${ }^{11} \mathrm{~m}^{2} / \mathrm{s}$ to $2.22 \times 10^{-10} \mathrm{~m}^{2} / \mathrm{s}$ for reducing sugars.

KEY-WORDS: Debittering - Diffusion - Green olives Reducing sugars - Sodium chloride.

\section{INTRODUCTION}

The diffusion of solutes in food products plays an important role in many food processes, such as extraction of lipids and sugars, drying, chemical peeling, etc., as well as the processing of fermented green olives.

Several researchers have studied the diffusion of $\mathrm{NaCl}$ by soaking vegetable pieces in salt solutions at different temperatures and determining the salt intake by the tissues.

Liu (1992) determined the apparent diffusion coefficient of salt in potato tissue immersed in different brines with sodium chloride concentrations between 1 and $5 \%(w / v)$, at temperatures between $50^{\circ} \mathrm{C}$ and $120^{\circ} \mathrm{C}$.

During salting, sensory, chemical, and physical changes occur in vegetables due to the high ionic strength of the medium. (Liu, 1992).

Drusas, et al. (1988) quantified the diffusion of sodium chloride into green olives placed in brines of various concentrations. They studied untreated olives and olives pretreated with lye at $1.8 \%$ for 6 hours and calculated salt effective diffusion coefficients assuming a hollow sphere geometry and negligible external resistance to mass transfer. They measured the absorption of salt from changes in brine concentration.

The final in the fermentation of green olives is the lactic fermentation process that takes place during curing in brine. Due to the diffusion of sugars and other nutrients out of the olives, the brine becomes an appropriate growth medium for the microorganisms responsible for lactic fermentation (Bobillo and Marshall, 1991; Marsilio and Lanza, 1998) which provides the acidity necessary for the stability and preservation of the olives (Marsilio, 1990).

The factors that influence this diffusion process are olive variety, lye treatment, rinsing, olive/brine ratio and brine concentration, among others (Fernández Diez, 1985).

Brine concentration is of upmost importance in the fermentation process. A high concentration will inhibit the growth of microorganisms responsible for causing defects, but also hinder the growth of lactic bacteria. Whereas a lower brine concentration facilitates an earlier and more vigorous growth of these bacteria, impeding the development of other microorganisms. (Fernández Diez, 1985).

According to Durán Quintana et al. (1997), fermentations with brine concentrations above $8 \%$ 
practically inhibit the growth of lactic bacteria entirely. They indicate that a concentration of $6 \%$ of $\mathrm{NaCl}$ inhibits about 33\% of the bacteria, at a $7 \%$ concentration of salt the inhibition reaches $50 \%$, while at $8 \%$ only $10 \%$ of bacteria survive and a $9 \%$ $\mathrm{NaCl}$ concentration causes total inhibition.

Recently, Maldonado et al. (2008) studied the influence of different concentrations of lye on the diffusion of reducing sugars during curing.

Due to the importance of the availability of reducing sugars in the brine for the fermentation process and considering that, to date, the diffusion phenomena of reducing sugars has not been quantified from a mass transfer standpoint in olives in terms of brine concentration, the aim of the present work is to evaluate the diffusion of sugar and sodium chloride during the curing process of green olives of the local variety "Arauco", as affected by different brine concentrations.

\section{MATERIALS AND METHODS}

\subsection{Sampling}

Green olives of the variety "Arauco" were used in this study. They were harvested with a Maturity Index (M.I.) 2 (Fernández et al. 1991), corresponding to a green-yellow skin color, with few red spots. The M.I. scale ranges from 0 for olives with a skin color of intense green to 7 for olives with black skin and totally purple flesh. A random sample of $50 \mathrm{~kg}$ of olives previously graded was selected for the experiments, from these, 150 olives were measured giving the following average dimensions: weight $=7.433 \times 10^{-3} \mathrm{~kg}, \quad \sigma=0.915 \times 10^{-3} \mathrm{~kg}$; equatorial diameter $=20.50 \times 10^{-3} \mathrm{~m}, \sigma=1.59 \times 10^{-3}$ $\mathrm{m}$; length $=31.38 \times 10^{-3} \mathrm{~m}, \sigma=2.20 \times 10^{-3} \mathrm{~m}$. Twenty five olives gave the following skin thickness = $4.0 \times 10^{-5} \mathrm{~m}$. The skin was removed with the help of a sharp thin blade, taking care to eliminate any mesocarpic cells attached and to avoid cuts and breakage of the skin. The skin thickness was measured with a digital caliper Palmer Helios (1:100 mm).

Batches of $4.5 \mathrm{~kg}$ olives each were taken from the previous sample and placed in 10-liter plastic containers with lids, into which 3 liters of treatment solutions (lye, water and brine) were added at each stage. The temperature was kept constant a $20{ }^{\circ} \mathrm{C}$ $\pm 1{ }^{\circ} \mathrm{C}$, throughout the processes. Each treatment was applied in triplicate.

The concentration of $\mathrm{NaOH}$ studied was $2.50 \%$ $(w / v)$. As a customary industry practice, the debittering process was terminated when the lye had penetrated $3 / 4$ of the flesh thickness, which was visually determined by a colorimetric reaction with phenolphthalein. The debittering process took 10 hours.

After the debittering process, the lye was removed from the containers and the olives were rinsed with tap water for two consecutive periods of six hours each. At the end of each rinsing period, the water was completely removed from the containers. Finally, 3 liters of brine with 7\%, 10\% y $13 \%$ sodium chloride concentration, acidified with $0.2 \%(\mathrm{v} / \mathrm{v})$ of each acetic and hydrochloric acid (Merck, PA), were added to the containers. In order to inhibit microbial activity $1000 \mathrm{Ul} / \mathrm{ml}$ of nisine (Chrisin ${ }^{\mathrm{TM}}$ ) and $50 \mathrm{ppm}$ of chloranphenicol (Avicloran ${ }^{\mathrm{TM}}$ ) were also added to the brines. The microbial inhibition was checked by periodical microbial analysis (ICMSF, 1986).

The containers with the solutions and the olives were maintained in continuous agitation in order to achieve a large surface mass transfer coefficient (large Biot number).

Brine samples were taken periodically. The samples were placed in plastic test tubes, sealed and kept in a freezer at $-18{ }^{\circ} \mathrm{C}$ until they were analyzed.

\subsection{Analytical Methods}

The concentration of $\mathrm{NaCl}$ in the brines was measured by Mohr's method (Skoog and West, 1976; Maldonado et al., 2008).

Reducing sugars in brine were determined by Miller's technique (Miller, 1959; Maldonado et al., 2008), employing a Metrolab ${ }^{\circledR} \quad$ UV-visible spectrophotometer.

Miller's technique was adapted to determine reducing sugars in olive flesh (Maldonado et al., 2008).

The salt absorbed by the olives was calculated from the changes in brine concentration.

The concentration of reducing sugars in the olives was measured before the debittering process and at the end of the second rinsing. During the curing process, it was calculated from the increase in sugars in the brine.

\subsection{Theoretical Considerations}

In order to calculate the effective diffusion coefficients of both solutes in the skin and the flesh during the curing process, a diffusion model for a composite hollow sphere was adjusted to the experimental data, using the following assumptions (Maldonado and Zuritz, 2004). See Figure 1.

1. The flesh and skin of the olives are homogeneous and isotropic with a uniform initial concentration $\left(c_{i}\right)$.

2. The olive flesh is a hollow sphere with internal radius $r_{i}$ and external radius $r_{0}$, surrounded by the skin of internal radius $r_{0}$ and external radius $r_{s}$.

3. The thickness of the skin is much less than the internal and external radii, therefore, the difference in surface areas can be neglected.

4. Provided that $\left(r_{s}-r_{o}\right)<<\left(r_{o}-r_{i}\right)$, the accumulation of sodium in the skin can be neglected allowing the assumption of a quasi-steady state diffusion process through the skin. 
5. The pit is a concentric solid sphere impervious to the diffusion of solutes.

6. As a simplifying assumption, the model considers constant effective diffusion coefficients in both the skin $\left(D_{S}\right)$ and the flesh $\left(D_{F}\right)$.

7. The system is well-agitated (large mass Biot number) therefore, the outer skin surface $\left(r=r_{s}\right)$ reaches the solution average concentration $\left(\mathrm{C}_{\mathrm{s}}\right)$.

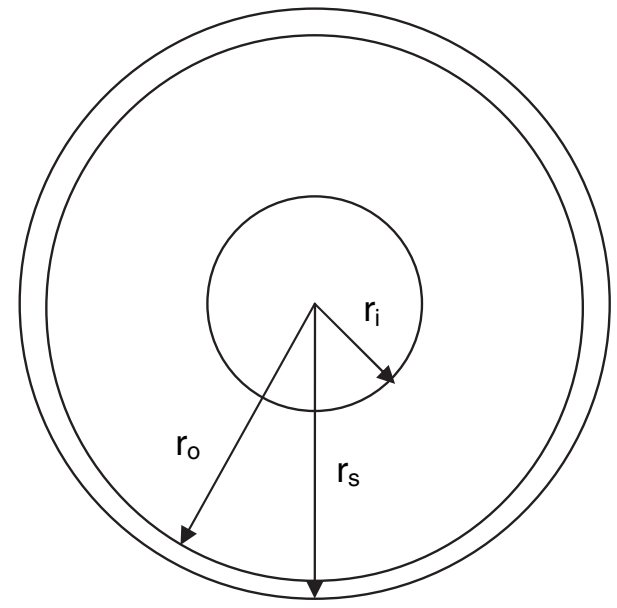

Figure 1

Schematic of olive cross section showing radial dimensions.

Under the above conditions, the onedimensional diffusion process with constant effective diffusion coefficients through the flesh $\left(D_{F}\right)$ and the skin $\left(D_{S}\right)$ is expressed in dimensionless form as:

$\frac{\partial^{2} \mathrm{C}}{\partial R^{2}}+\frac{2}{R} \frac{\partial C}{\partial R}=\frac{\partial C}{\partial \theta}$

Equation (1) is subjected to the following initial and boundary conditions:

IC:

$$
\text { at } \theta=0 ; \quad \mathrm{C}=1 \quad \text { at } \mathrm{a}<\mathrm{R}<1
$$

$\mathrm{BC} 1: \quad$ at $\theta>0 \quad \partial \mathrm{C} / \partial \mathrm{R}=0 \quad$ at $\mathrm{R}=\mathrm{a}$

$\begin{array}{ll}\mathrm{BC} 2: & \text { at } \theta>0 \quad \partial \mathrm{C} / \partial \mathrm{R}=\left[-\frac{\mathrm{D}_{\mathrm{s}} /\left(r_{\mathrm{s}}-r_{c}\right)}{D_{F} / r_{c}}\right] C \\ \text { at } \mathrm{R}=1 & \text { (2c) }\end{array}$

Where:

$C=\left(c-c_{s}\right) /\left(c_{i}-c_{s}\right) ; \quad R=r / r_{0} ; \quad a=r_{i} / r_{0} ; \quad \theta=D_{F} t / r_{0}^{2}$

The olive dimensions were adjusted to the radial dimensions of an equivalent sphere of equal volume giving the following values: $r_{i}=4.29 \times 10^{-3} \mathrm{~m}$; $r_{0}=11.77 \times 10^{-3} \mathrm{~m} ; r_{\mathrm{s}}=11.81 \times 10^{-3} \mathrm{~m}$ and skin thickness $\left(r_{\mathrm{s}}-\mathrm{r}_{\mathrm{o}}\right)=4 \times 10^{-5} \mathrm{~m}$.

The average volumetric concentration $<\mathrm{C}>$ of the solution to equation (1) subjected to equations (2a-c) for large processing times was presented by Maldonado and Zuritz (2004) as:

$$
\langle c\rangle=\frac{6}{\left(1-a^{3}\right)} A_{\left(\alpha_{1}\right)}^{2} e^{-D_{F} \alpha_{1}^{2} t / r_{0}^{2}}
$$

where:

$A=\frac{\left(H^{2}+k_{2}^{2} \alpha_{1}^{2}\right)}{(1-a)\left(a^{2} \alpha_{1}^{2}+1\right)\left(k_{2}^{2} \alpha_{1}^{2}+H^{2}\right)+\left(H a+k_{2}\right)\left(H+a k_{2} \alpha_{1}^{2}\right)}$

and

$\left.\mathrm{R}_{(\alpha 1)}=(\mathrm{B} 1 * \mathrm{~B} 2)-(\mathrm{B} 3 * \mathrm{~B} 1)+\mathrm{a} \alpha_{1}(\mathrm{~B} 1 * \mathrm{~B} 4+\mathrm{B} 3 * \mathrm{~B} 2)\right]$

in which:

$\mathrm{B} 1=\frac{\cos \left(\alpha_{1} \mathrm{a}\right)}{\alpha_{1}}$

$\mathrm{B} 2=\left[\frac{1}{\alpha_{1}}\left(\operatorname{sen}\left(\alpha_{1}\right)-\operatorname{sen}\left(\alpha_{1} a\right)\right)+\left(\operatorname{acos}\left(\alpha_{1} a\right)-\cos \left(\alpha_{1}\right)\right)\right]$

B3 $=\frac{\operatorname{sen}\left(\alpha_{1} a\right)}{\alpha_{1}}$

$\mathrm{B} 4=\left[\frac{1}{\alpha_{1}}\left(\cos \left(\alpha_{1}\right)-\cos \left(\alpha_{1} a\right)\right)+\left(\operatorname{sen}\left(\alpha_{1}\right)-\operatorname{asen}\left(\alpha_{1} a\right)\right)\right]$

Where $\alpha_{1}$ are the eigenvalues that satisfy the following equation:

$\left[\frac{k_{2}}{k_{1}}-\left(1+a \alpha_{1}^{2}\right)\right] \operatorname{sen}\left[(1-a) \alpha_{1}\right]+\left[\begin{array}{lll}\alpha_{1} & a \frac{k_{2}}{k_{1}} \\ \frac{k_{1}}{2} & \left(\alpha_{1}-a\right. & \left.\alpha_{1}\right)\end{array}\right) \cos \left[(1-a) \alpha_{1}\right]=0$

where:

$\mathrm{H}=\mathrm{k}_{2}-\mathrm{k}_{1} ; \quad \mathrm{k}_{2}=\mathrm{D}_{\mathrm{S}} /\left(\mathrm{r}_{\mathrm{S}}-\mathrm{r}_{\mathrm{o}}\right) ; \quad \mathrm{k}_{1}=\mathrm{D}_{\mathrm{F}} / \mathrm{r}_{\mathrm{o}}$

The flesh and skin effective diffusion coefficients $\left(D_{F}\right.$ and $\left.D_{S}\right)$ and the eigenvalues $\left(\alpha_{1}\right)$ for each treatment were estimated using the least squares method, which minimizes the function:

$\mathrm{S}=\sum_{\mathrm{i}=1}^{\mathrm{N}}\left(\langle\mathrm{C}\rangle_{\text {exp. }}-\langle\mathrm{C}\rangle_{\text {calc. }}\right)^{2}$

Since the sum of squares of the residuals given as equation (11) is a non-linear function of the flesh and skin effective diffusion coefficients $\left(D_{F}\right.$ and $D_{S}$ ) and the eigenvalues $a_{1}$, the interactive non-linear regression method implemented in the program Microsoft Excel Solver" was used minimizing equation (11) simultaneously subjected to the restriction imposed by equation (10). 


\section{RESULTS AND DISCUSSION}

The initial content of reducing sugars in the olives was $74.94 \mathrm{~g} / \mathrm{kg}$. After 10 hours of debittering and two rinsing processes of 6 hours each, the remaining concentration of reducing sugars was $22.03 \mathrm{~g} / \mathrm{kg}$, which corresponds to a loss of $70.6 \%$.

Figures 2 and 3 show respectively the experimental data of the average concentrations of sodium chloride and reducing sugars in the brines for the three treatments.

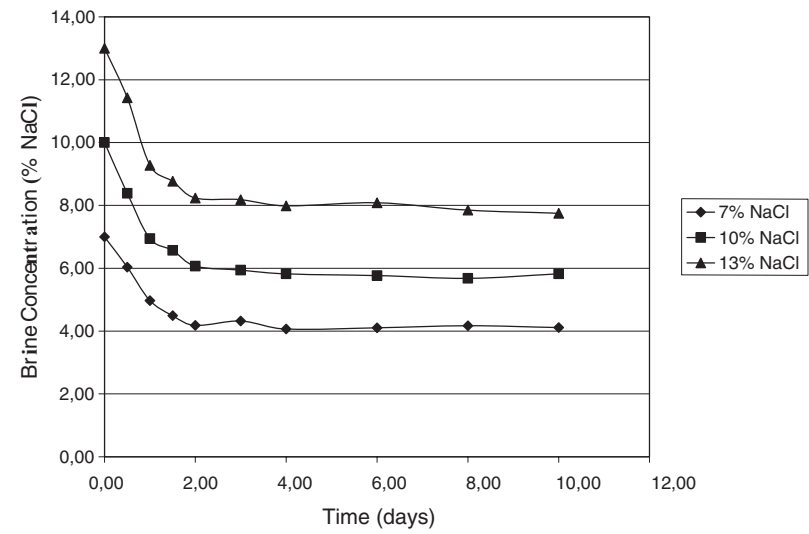

Figure 2

Concentration of sodium chloride in brine $(\% \mathrm{w} / \mathrm{v})$ until equilibrium, for curing treatments with brines at 7,10 and $13 \% \mathrm{NaCl}$.

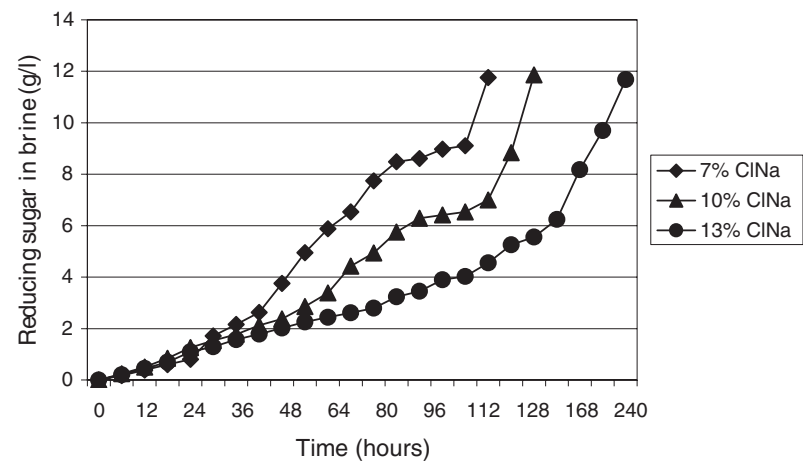

Figure 3

Concentration of reducing sugars in brine $(\mathrm{g} / \mathrm{l})$ until maximum concentration, for curing

treatments with brines at 7,10 and $13 \% \mathrm{NaCl}$.

After the second day, the concentration of $\mathrm{NaCl}$ remains almost constant for the rest of the curing process. The salt concentration decreases around 59,58 and $60 \%$ for brines at $7 \%, 10$ and $13 \%$ respectively. On the other hand, the three treatments extracted practically the same amount of reducing sugars $(11.76,11.86$ and $11.68 \mathrm{~g} / \mathrm{l}$ for brines at $7 \%, 10 \%$ and $13 \%$ of $\mathrm{NaCl}$ ), but this amount was reached at 120, 144 y 288 hours, respectively. However, at a given time, the brine with lower salt concentration had extracted more sugar than the other brines, e.g. at 88 hours the concentration of sugar in the brines was respectively $8.48,5.75$ and $3.24 \mathrm{~g} / \mathrm{l}$ for brines with
$7 \%, 10 \%$ and $13 \% \mathrm{NaCl}$. Similar results were found by Rodriguez de la Borbolla y Alcalá y Rejano (1979) studying brine concentrations between $4 \%$ and $14 \%$.

The diffusion of $\mathrm{NaCl}$ into the olive flesh is shown in Figure 4. The average equilibrium concentration of $\mathrm{NaCl}$ in the olive flesh was about 19,27 and $32 \mathrm{~g} \mathrm{NaCl} / \mathrm{kg}$ of flesh in brines at $7 \%$, $10 \%$ and $13 \%$ respectively. Nevertheless, the time required to reach the equilibrium concentration was inversely proportional to brine concentration, i.e.: 42 hours with brine at $13 \% \mathrm{NaCl}, 56$ hours with brine at $10 \% \mathrm{NaCl}$ and 64 hours with brine at $7 \% \mathrm{NaCl}$.

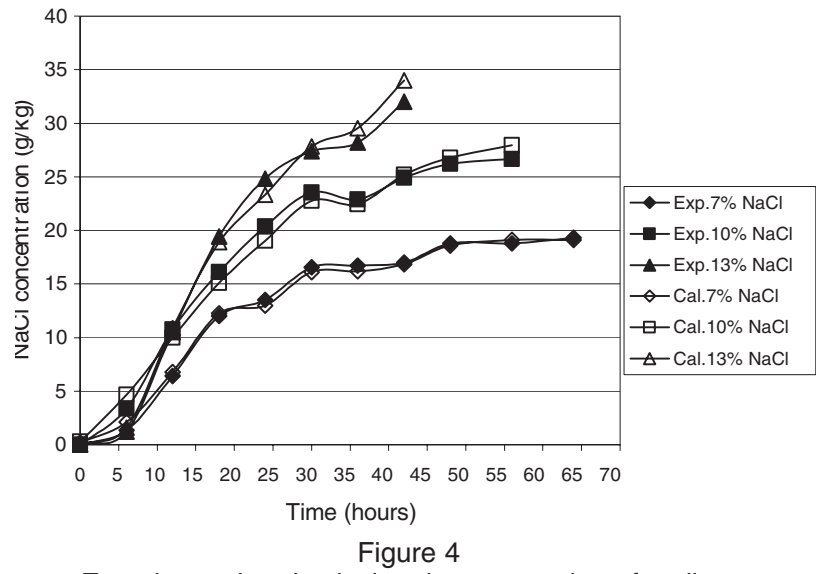

Experimental and calculated concentration of sodium chloride in olive flesh $(\mathrm{g} / \mathrm{kg})$ until equilibrium, for curing treatments with brines at 7,10 and $13 \% \mathrm{NaCl}$.

Figure 5 shows the decrease of reducing sugars in the flesh during the curing process, up to the time of maximum concentration in the brine. The remaining average concentration of sugars were $14.19,14.12,14.24 \mathrm{~g} / \mathrm{kg}$ of flesh for brines at $7 \%$, $10 \%$ and $13 \%$ respectively. These values represent around $64.5 \%$ of the concentration of sugar at the beginning of the curing process. Both figures 4 and 5 show the values calculated with the model (equation 3).

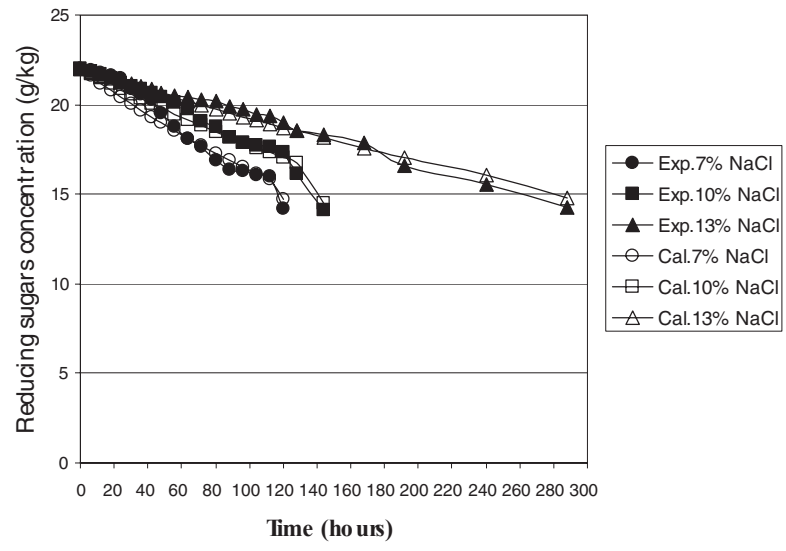

Figure 5

Experimental and calculated concentration of reducing sugars in olive flesh $(\mathrm{g} / \mathrm{kg})$, for

curing treatments with brines at 7, 10 and $13 \% \mathrm{NaCl}$. 
This difference in solute diffusivity could be due to the difference in molecular size between the glucose and the $\mathrm{NaCl}$. Since the molecule of glucose is much larger than the molecule of $\mathrm{NaCl}$, it would be expected that the movement out of the flesh of the former would be slower than the entry of the later into the olive.

Other reasons postulated are that during osmotic processing, the rate of diffusion of water from any vegetable tissue depends on the concentration and temperature of the osmotic solution, size and geometry of the material, solution to material mass ratio, and level of agitation of the solution (RaoultWack et al., 1989; Raoult-Wack, 1994; Rastogi and Niranjan, 1998; Rastogi et al., 1999).

The effective diffusion coefficients of reducing sugars and $\mathrm{NaCl}$ calculated for the flesh $\left(D_{\mathrm{F}}\right)$ and the skin $\left(D_{S}\right)$ are presented in Table 1.

Table 1

Effective diffusion coefficients for reducing sugars and sodium chloride in flesh $\left(D_{F}\right)$ and skin $\left(D_{S}\right)$ of olives cured with different concentrations of $\mathrm{NaCl}$.

\begin{tabular}{lccc}
\hline Solute & Treatment & $\mathbf{D}_{\mathrm{F}}\left(\mathrm{m}^{2} / \mathbf{s}\right)$ & $\mathbf{D}_{\mathrm{S}}\left(\mathrm{m}^{2} / \mathbf{s}\right)$ \\
\hline \multirow{3}{*}{$\begin{array}{l}\text { Reducing } \\
\text { Sugars }\end{array}$} & $7 \% \mathrm{NaCl}$ & $2.216 \times 10^{-10}$ & $1.877 \times 10^{-13}$ \\
& $10 \% \mathrm{NaCl}$ & $1.570 \times 10^{-10}$ & $1.331 \times 10^{-13}$ \\
& $7 \% \mathrm{NaCl}$ & $9.759 \times 10^{-11}$ & $8.278 \times 10^{-14}$ \\
\multirow{3}{*}{$\begin{array}{l}\text { Sodium } \\
\text { chloride }\end{array}$} & $10 \% \mathrm{NaCl}$ & $3.178 \times 10^{-9}$ & $3.101 \times 10^{-13}$ \\
& $13 \% \mathrm{NaCl}$ & $3.996 \times 10^{-9}$ & $4.035 \times 10^{-13}$ \\
\hline
\end{tabular}

In the flesh, the diffusion coefficients $\left(D_{F}\right)$ for reducing sugars were between one and two order of magnitude smaller than the coefficients for sodium chloride. For instance, in treatment for brine concentration at $7.0 \% \mathrm{NaCl}$, the $\mathrm{D}_{\mathrm{F}}$ for reducing sugars was $2,216 \times 10^{-10} \mathrm{~m}^{2} / \mathrm{s}$, while for $\mathrm{NaCl}$ this value was $2,920 \times 10^{-9} \mathrm{~m}^{2} / \mathrm{s}$. As indicated above, the difference in magnitude between the flesh diffusion coefficients could be attributed to the difference in molecular size between the glucose and the $\mathrm{NaCl}$.

In addition, the data seem to indicate that for reducing sugars, an increase in brine concentration gives rise to smaller values of $D_{F}$. For instance, $D_{F}$ decreased from a value of $2.216 \times 10^{-10} \mathrm{~m}^{2} / \mathrm{s}$ for a brine concentration at $7.0 \% \mathrm{NaCl}$, to $1.57 \times 10^{-10}$ $\mathrm{m}^{2} / \mathrm{s}$ and $9.759 \times 10^{-11} \mathrm{~m}^{2} / \mathrm{s}$ for brine concentrations at $10 \%$ and $13 \%$, respectively. However, an opposite behavior was observed for the $D_{F}$ values of $\mathrm{NaCl}$. This difference in behavior could be explained by the effect that the brine's osmotic pressure probably exerts on the diffusion of solutes in and out of the olive flesh. An increase in osmotic pressure on the outside would provoke a faster diffusion of solutes $(\mathrm{NaCl})$ into the olive flesh, but would have an inverse effect with regard to solutes diffusing out of the flesh (reducing sugars).
With regard to the skin effective diffusion coefficient $\left(D_{S}\right)$, while their values were of the same order of magnitude for both solutes, they were three orders of magnitude lower than the $D_{F}$ values for reducing sugars and four orders of magnitude lower than the $\mathrm{D}_{\mathrm{F}}$ for $\mathrm{NaCl}$. These values are consistent with those reported by Maldonado et al. (2008), for the diffusion of reducing sugars and $\mathrm{NaCl}$ in olives treated with different lye concentrations.

Although in the skin the effect is not as noticeable as in the flesh, the skin presented a greater barrier effect for the diffusion of reducing sugars than for $\mathrm{NaCl}$, and the diffusion coefficients for $\mathrm{NaCl}$ were slightly larger than for reducing sugars. For instance, for olives treated with a brine concentration at $13.0 \% \mathrm{NaCl}$, the $\mathrm{D}_{\mathrm{S}}$ for reducing sugars was $8.278 \times 10^{-14} \mathrm{~m}^{2} / \mathrm{s}$, while for $\mathrm{NaCl}$ it was $4.035 \times 10^{-13} \mathrm{~m}^{2} / \mathrm{s}$.

As with the flesh diffusion coefficients, the same effect of brine osmotic pressure was observed with the skin diffusion coefficients.

This difference in diffusivity values is probably due to the different physical structures between the flesh and the skin, which, being the natural barrier of the fruit, has a more impervious structure to the diffusion of different chemical compounds, such as reducing sugars and $\mathrm{NaCl}$.

Drusas et al. (1988) reported values of effective diffusion coefficients for sodium chloride in green olives of the variety Konservolea at $20^{\circ} \mathrm{C}$, in the order of $1.95 \times 10^{-10} \mathrm{~m}^{2} / \mathrm{s}$ for a brine concentration of $10.7 \%$ in olives pretreated with lye at $1.8 \%$ for 6 hours. The difference in the reported values and the ones presented in Table 1 is probably due to the different variety studied and lower lye concentration and debittering time used. The structural difference of the two varieties could also be reflected in the time required to attain a constant concentration of $\mathrm{NaCl}$ in the brine. They reported 50 days, while in the present case it took only two days. Furthermore, they calculated values of "overall" effective diffusion coefficients (which include the effect of the skin), while the present values differentiate the resistance of the flesh from the resistance of the skin to the diffusion process.

Nonetheless, the $D_{F}$ values in Table 1 are within the same order of magnitude of those presented by Pflug et al. (1967), Desai (1977) and Bomben et al. (1974) for the diffusivity of $\mathrm{NaCl}$ in pickled cucumbers, as well as for other foodstuffs (Stahl and Loncin, 1979; Wood, 1966; Kormendy and Ganter, 1958). For instance, Pflug et al. (1967) reported diffusivity values from $8.4 \times 10^{-10}$ to $3.02 \times 10^{-9}$ $\mathrm{m}^{2} / \mathrm{s}$ for pickled cucumbers of different diameters working at temperatures between $21^{\circ} \mathrm{C}$ and $71^{\circ} \mathrm{C}$, while Desai (1977) calculated values ranging from $4.0 \times 10^{-10}$ to $1.2 \times 10^{-9} \mathrm{~m}^{2} / \mathrm{s}$ for pickled cucumbers and potato slices at $24{ }^{\circ} \mathrm{C}$ and $25{ }^{\circ} \mathrm{C}$. For his part, Bomben et al. (1974) found values on the order of $5.3 \times 10^{-10}$ to $1.5 \times 10^{-9} \mathrm{~m}^{2} / \mathrm{s}$ at temperatures of $25^{\circ} \mathrm{C}$ and $49^{\circ} \mathrm{C}$ respectively.

In closing, it can be said that since the nutrients, particularly reducing sugars, needed for the growth 
of the microorganisms responsible for lactic fermentation, that will provide the acidity necessary for stability and preservation, coming from within the olives, a large initial concentration of sugars in the brine at the beginning of the curing process is desirable as it would insure a more complete fermentation which will translate into a more acidic medium in less time.

From the present data, we can see that increasing the concentration of $\mathrm{NaCl}$ in the brine is ineffective with regard to the extraction of reducing sugars, since we can achieve the same concentration of this solute with less brine concentration and in much less time.

\section{CONCLUSIONS}

The loss of reducing sugars from, and the diffusion of sodium chloride into the olive variety Arauco, treated with brines of different concentrations of $\mathrm{NaCl}(7.0 \%, 10.0 \%$ and $13.0 \%)$ were quantified. During the curing process, the maximum concentration of sugar extracted was almost the same for the three brine concentrations studied, although the time required to attain this maximum concentration was directly proportional to brine concentration. Effective diffusion coefficients of both solutes in the skin and the flesh were calculated for the curing period by adjusting a diffusion model for a composite hollow sphere, consisting of a thin skin and a thicker flesh, with constant flesh and skin effective diffusion coefficients $\left(D_{F}\right.$ and $\left.D_{S}\right)$ to the experimental data. The flesh effective diffusion coefficients $\left(D_{F}\right)$ varied from $2.92 \times 10^{-9} \mathrm{~m}^{2} / \mathrm{s}$ to $3.99 \times 10^{-9} \mathrm{~m}^{2} / \mathrm{s}$ for $\mathrm{NaCl}$ and from $9.76 \times 10^{-11} \mathrm{~m}^{2} / \mathrm{s}$ to $2.22 \times 10^{-10} \mathrm{~m}^{2} / \mathrm{s}$ for reducing sugars. With increasing brine concentration, the flesh diffusion coefficients increased for $\mathrm{NaCl}$ and decreased for reducing sugars. The skin effective diffusion coefficients $\left(D_{S}\right)$ for both solutes ranged from $8.27 \times 10^{-14} \mathrm{~m}^{2} / \mathrm{s}$ to $4.04 \times 10^{-13} \mathrm{~m}^{2} / \mathrm{s}$ and presented the same behavior as the flesh coefficients with increasing brine concentration. The same concentration of reducing sugars (needed for the lactic fermentation) can be attained with lower brine concentration in much less time.

\section{ACKNOWLEDGEMENTS}

Facultad de Ciencias Agrarias, Universidad Nacional de Cuyo, Alte. Brown 500, (5505) Chacras de Coria, Mendoza, Argentina Establecimiento Olivícola Atilio Avena e Hijos S.A., Mendoza, Argentina.

\section{NOMENCLATURE}

Dimensionless internal radius of the hollow sphere.

A Defined in equation (4)
B1 Defined in equation (6)

B2 Defined in equation (7)

B3 Defined in equation (8)

B4 Defined in equation (9)

C Dimensionless solute concentration

$<C>$ Dimensionless volume average solute concentration

c Solute concentration within the olive flesh ( $\mathrm{g} / \mathrm{kg}$ olive flesh)

$\mathrm{c}_{\mathrm{i}} \quad$ Initial solute concentration ( $\mathrm{g} / \mathrm{kg}$ olive flesh)

$c_{s}$ Solute concentration at the outer skin surface ( $\mathrm{g} / \mathrm{kg}$ olive flesh)

$D_{F} \quad$ Flesh effective diffusion coefficient $\left(\mathrm{m}^{2} / \mathrm{s}\right)$

$D_{S} \quad$ Skin effective diffusion coefficient $\left(\mathrm{m}^{2} / \mathrm{s}\right)$

$\mathrm{H}=\mathrm{k}_{2}-\mathrm{k}_{1}$

$\mathrm{k}_{1}=\mathrm{D}_{\mathrm{F}} / \mathrm{r}_{0}$

$k_{2} \quad=D_{S} /\left(r_{s}-r_{0}\right)$

$r \quad$ Radial position in the olive flesh $(m)$

$r_{i} \quad$ Internal radius of the olive flesh $(m)$

$r_{0} \quad$ External radius of the olive flesh and internal radius of the olive skin $(\mathrm{m})$

$r_{s} \quad$ External radius of the olive skin $(m)$

$\mathrm{R}$ Dimensionless radius

$R_{(\alpha 1)}$ Variable defined in equation (5)

$\mathrm{t}$ Time (s)

$\alpha_{1} \quad$ Eigenvalues

$\theta \quad$ Dimensionless time

\section{REFERENCES}

Bobillo M, Marshall VM. 1991. Effect of salt and culture aeration on lactate and acetate production by Lactobacillus plantarum. Food Microbiol. 8,153-160.

Bomben JL, Durkee EL, Lowe E, Secor GE. 1974. A laboratory study of countercurrent desalting of pickles. J. Food Sci. 39, 260-268.

Desai MH. 1977. Analysis of non-equilibrium multistage countercurrent leaching system. Ph. D. Thesis, Food Eng. Dept., University of Massachusetts Amherst.

Drusas A, Vagenas GK, Saravacos GD. 1988. Diffusion of sodium chloride in green olives. J. Food Eng. 7, 211222.

Durán Quintana MC, Barranco RC, García García P, Brenes Balbuena M, Garrido Fernández A. 1997. Bacterias del ácido láctico en la fermentación de aceitunas de mesa. Grasas Aceites. 48, 297-311.

Fernández MH, Uceda Ojeda M, García-Ortiz Rodríguez A, Morales Bernardino J, Friaz Ruiz L, Fernández García A. 1991. Apuntes: Elaboración de aceite de oliva de calidad. Junta de Andalucía Consejería de Agricultura y Pesca. 5/91, 36-38.

Fernández-Diez MJ. 1985. Biotecnología de la aceituna de mesa. Publicaciones CSIC. Sevilla, Madrid.

ICMSF. Microorganisms in Foods 2: Sampling for microbiological analysis: Principles and specific applications. 2nd Ed. 1986. Toronto. University of Toronto Press.

Kormendy L and Ganter G. 1958. Zlebensittel utersuchun Forsch.107:113. In Wood (1966).

Liu H. 1992. A kinetic study of salt diffusion in potato at high temperature. Int. J. Food Sci. Tech. 27, 443-455.

Maldonado MB, Zuritz CA. 2004. Difusión de sodio durante el tratamiento alcalino de aceitunas variedad Aloreña. Grasas Aceites 55, 409-414. 
Maldonado MB, Zuritz CA, Assof M. 2008. Diffusion of glucose and sodium chloride in green olives during curing as affected by lye treatment. J. Food Eng. 84, 224-230.

Marsilio V. 1990. Estado de la investigación sobre las aceitunas de mesa del Instituto Experimental de Elaiotecnia de Pesacara. Olivae 33, 30-42.

Marsilio V, Lanza B. 1998. Characterization of an oleuropein degrading strain of Lactobacillus plantarum. Combined effects of compounds present in olive fermenting brines (phenols, glucose and $\mathrm{NaCl}$ ) on bacterial activity. J. Sci. Food Agric. 76, 520 524.

Miller GL. 1959. Use of dinitrosalicylic acid reagent for determination of reducing sugar. Anal. Chem. 31, 426-428.

Pflug IJ, Fellers PJ, Gurevitz D. 1967. Diffusion rates in the desalting of pickles. Food Tech. 21, 1634-1638.

Raoult-Wack AL. 1994. Advances in osmotic dehydration. Trends Food Sci. Tech. 5, 255-260.

Raoult-Wack AL, Lafont F, Rios G, Guilbert S. 1989. Osmotic dehydration: Study of mass transfer in terms of engineering properties. In A. S. Mujjumdar \& $\mathrm{M}$. Roques (Eds.), Drying '89 (pp. 487-495). Hemisphere.

Rastogi NK, Niranjan K. 1998. Enhanced mass transfer during osmotic dehydration of high pressure treated pineapple. J. Food Sci. 63, 508-511.

Rastogi NK, Eshtisghi MN, Knorr D. 1999. Accelerated mass transfer during osmotic dehydration of high intensity electrical fieldpulse pretreated carrots. J. Food Sci. 64, 1020-1023.

Rodriguez de la Borbolla y Alcalá JM, Rejano NL. 1979. Sobre la preparación de aceitunas de estilo sevillano. La fermentación I. Grasas aceites. 30, 175-185.

Skoog DF, West DM. 1976. Fundamentals of analytical chemistry. Holt, Rinehart and Winston, New York.

Stahl R, Loncin M. 1979. Prediction of diffusion in solid foodstuffs. J. Food Process. Pres. 3, 213-223.

Wood, F. W. 1966. The diffusion of salt in pork muscle and fat tissue. J. Sci. Food Agric. 7, 138-140.

Recibido: 23/11/07 Aceptado: $22 / 2 / 08$ 